Отримано: 20 серпня 2021 року

Прорецензовано: 6 вересня 2021 року

Прийнято до друку: 20 вересня 2021 року

e-mail: g.tsapro@kubg.edu.ua

olgasivaeva1987@gmail.com

DOI: 10.25264/2519-2558-2021-11(79)-100-103
Tsapro G. Yu., Sivaieva O. S. Does Pandemic have a silver lining? A contrastive corpus study of collocations with Pandemic in media texts. Наукові записки Начіонального університету «Острозька академія»: серія «Філологія». Острог : Вид-во НаУОА, 2021. Вип. 11(79). С. 100-103.

Galyna Tsapro,

PhD (Linguistics), Associate Professor.

Borys Grinchenko Kyiv University

Olha Sivaieva,

Senior lecturer,

Polissia National University

\title{
DOES PANDEMIC HAVE A SILVER LINING? A CONTRASTIVE CORPUS STUDY OF COLLOCATIONS WITH PANDEMIC IN MEDIA TEXTS
}

The research is devoted to the contrastive corpus analysis of the semantic prosody of collocations with PANDEMIC in the broadsheet 'The Guardian' and the tabloid 'The Mirror'. The corpora have been processed with the help of Sketch Engine and the collocations with PANDEMIC have been analysed. The study mostly concentrates on the verbs with PANDEMIC as subject and object as most representative in media texts. The dictionary definition of PANDEMIC interprets it as a word with negative semantic prosody. The discourse analysis of the data obtained proves that collocations containing this collocate have negative semantic colouring as well. The following verbs start, hit, lead, cause, force, mean, devastate, which are common for both newspapers, represent PANDEMIC as a metaphorical image of a disaster, and the verbs specific for 'The Mirror' - bring, abate, inflict, scupper, kill, give, show, go on - support the given picture. However, the verbs unique for 'The Guardian' - strike, affect, shine, reveal, create, take, turn, remain - mostly outline the starting point or describe problems people have to face during pandemic times. Still some verbs in 'The Guardian', for example exacerbate and stop, also contribute to the frightening portrayal of a supernatural power terrorising humans. Both newspapers sketch personal stories, describe problems in business, trading, travelling, but 'The Guardian' puts more emphasis on international affairs and governments' decisions and responsibility.

Key words: semantic prosody, corpus analysis, PANDEMIC, media discourse, The Guardian, The Mirror.

\author{
Цапро Галина Юріївна, \\ кандидат філологічних наук, доиент, \\ Київький університет імені Бориса Грінченка \\ Сівасва Ольга Сергї̈вна, \\ стариий викладач, \\ Поліський національний університет
}

\section{ПОЗИТИВНЕ У ПАНДЕМІЇ? КОНТРАСТИВНИЙ КОРПУСНИЙ АНАЛІЗ СЛОВОСПОЛУЧЕНЬ 3 PANDEMIC У МЕДIА ТЕКСТАХ}

Статтю присвячено контрастивному корпусному аналізу семантичної просодії словосполучень з PANDEMIC у британській суспільно-політичній газеті «The Guardian» і таблої $i$ «The Mirror». Для проведення даного дослідження створено та проаналізовано за допомогою комn'ютерної програми Sketch Engine корпуси текстів, до складу яких входять словосполучення з PANDEMIC. Дослідження в основному базується на корпусному аналізі дієслів з PANDEMIC як підметом і додатком як найбільи репрезентативна група словосполучень у медіа-текстах. У словнику PANDEMIC визначено як слово, яке має негативну семантичну просодію. Дискурс-аналіз отриманих даних доводить, шо словосполучення з РANDEMIC також мають негативне семантичне забарвлення. Дієслова start, hit, lead, cause, force, mean, devastate, які вживаються в обох газетах, розкривають PANDEMIC як метафоричний образ катастрофи, а дієслова ring, abate, inflict, scupper, kill, give, show, go оп, які зустрічаються тільки у таблоїді «The Mirror», є цьому підтвердженням. Однак, лише у газеті «The Guardian» дієслова strike, affect, shine, reveal, create, take, turn, remain в основному відображають відправну точку або описують проблеми, з якими людям довелося зіткнутися в часи пандемії. Проте деякі дієслова в газеті «The Guardian», наприклад, exacerbate та stop, також підкреслюють ту страхітливу надприродну силу, яка тероризує людей. Як суспільно-політична газета «The Guardian», так і таблоїд «Тhe Міrror» розкривають особисті історії, описують проблеми в бізнесі, торгівлі та під час подорожей, але саме в статтях газети «Тhе Gиагdian» більше уваги приділяється міжнародним справам та рішенням урядів і відповідальності.

Ключові слова: семантична просодія, корпусний аналіз, PANDEMIC, медійний дискурс, The Guardian, The Mirror.

Introduction. The aim of the research is to determine discursive peculiarities of collocations with PANDEMIC in The Guardian [11] and The Mirror [12] issues published in 2020-2021. Considering the aim, the following objectives have been set forward: 1) to create and process the broadsheet and the tabloid corpora; 2) to analyse and compare discursive features of collocations with $P A N D E M I C$ in the two newspapers singling out specific discursive characteristics presented in each newspaper. The methodology of the research includes 1) corpus analysis, which with the help of Sketch Engine [8] enables to retrieve collocations with $P A N D E M I C$ from the media texts corpora; 2) discourse analysis, which allows to reveal semantic prosody of collocations with $P A N D E M I C$ in the media texts and to interpret meanings of text passages containing collocations with PANDEMIC as well as to examine and establish metaphorical images created in the studied text passages; 3 ) comparative analysis, which provides two correlative media pictures of $P A N D E M I C$ reflected in articles of the two British newspapers.

Literature overview. Numerous linguistic studies have been devoted to Semantic Prosody $[1 ; 3 ; 7 ; 9]$ and Corpus Linguistics [4; $5 ; 10 ; 13]$ during the last 30 years. The term semantic prosody was firstly introduced by B. Louw [3, p. 158] in 1993, which was defined as consistent aura of meaning with which a form is imbued by its collocates. W. Bublitz [1, p. 9] in his work "Semantic 
Prosody and Cohesive Company" highlights that words can have a specific halo or profile, which may be positive, pleasant and good, or else negative, unpleasant and bad. Thus, semantic prosody shows the attitude of a writer or speaker in a text. Semantic prosody is closely related to connotation and context. Words or phrases can have negative or positive semantic prosodies if words or phrases are accompanied by lexical units with negative and positive meanings. Some words have a predominantly negative prosody, a few have a positive prosody, and many words are neutral. Moreover, if the collocates which are combined with a node word are mostly of strong negative semantic characteristics, the node word bears a strong negative prosody; if the collocates are mainly positive words, then the node word is endowed with a positive prosody; if both positive and negative collocates exist in the context, the node word can be said to bear a neutral prosody [9, p. 160]. J. Sinclair [7, p. 87] stresses on the fact that semantic prosodies are evaluative or attitudinal and are used to express the speaker's approval (positive prosody) or disapproval (negative prosody) of whatever topic is momentarily the object of discourse.

It should be mentioned that most of the studies investigating semantic prosody have been based on large general language corpora. A corpus is therefore a 'body' of language, or more specifically, a very large collection of naturally occurring language, stored as computer files. T. McEnery and A. Hardie in 2011 in their work "Corpus Linguistics: Method, Theory and Practice" [4] mention that corpus linguistics study language acquiring explanation or description, also emphasizing that Corpus Linguistics is a quantitative methodology, which means that corpus linguistics mostly deals with numbers reflecting frequencies of words and phrases in corpora.

However, nowadays Corpus Linguistics is seen not only as a methodology but as a theory of language as well, and very often it combines both. According to T. McEnery and A. Wilson [5, p. 1] it was conceived as nothing but a methodology, created from a set of theoretical principles about language, although it could be argued that more recently it has been used to advance theories about language use [2]. W. Teubert [10, p. 4] states that Corpus Linguistics is not a method but an insistence on working only with real language data taken from the discourse in a principled way and compiled into a corpus, and E. Tognini-Bonelli [13, p. 1], supporting the mentioned above idea, argues that Corpus Linguistics has gone well beyond [its] methodological role and has become an independent field of linguistics.

Results and Discussion. The newspaper has been the centre of news industry for several hundred years and despite the growth of digital media newspapers are still read either in print or on a website or in a mobile app [14, p. 227]. Media discourse, firstly newspaper texts, reflects what is going on all over the world at the present. Thus, the urgent issues of pandemic have received a lot of media attention recently. Broadsheets and tabloids highlight the most crucial concerns connected with the Covid-19 pandemic. In our research we have analysed and compared how PANDEMIC is verbally portrayed in The Guardian and The Mirror articles.

The word pandemic has negative connotation, as it is defined as an occurrence of a disease that affects many people across a whole country or the whole world [6]. In this way, collocations with the lemma PANDEMIC have negative semantic prosody as well. However, discourse analysis of newspaper text passages demonstrates that despite the negative semantic prosody of the collocations with $P A N D E M I C$ and clearly negative metaphoric pictures created in the articles there are some examples of positive consequences caused by pandemic.

The processed corpora of two newspapers published recently present similar and different collocations with $P A N D E M I C$ in the following patterns: $P A N D E M I C+$ verb as subject and verb+PANDEMIC as object, which was the basis of this research. The following n-grams (see Pic. 1 and Pic. 2) illustrate collocations with PANDEMIC from the two corpora. The frequency use of the lemma PANDEMIC as noun is 223 in The Guardian corpus, and it is 82 in The Mirror corpus, which demonstrates that the broadsheet has addressed the topic almost three times more often than the tabloid.

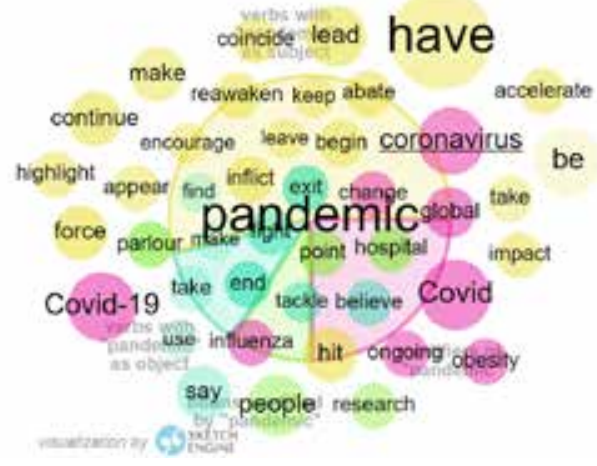

Picture 1. The n-gram of collocations with PANDEMIC in The Mirror

Common verbs in the pattern PANDEMIC+verb as subject for both newspapers are the following: start, hit, lead, cause, force, mean, devastate (e.g., Gupta's companies have been in trouble since the pandemic caused disruption last year, but his difficulties were compounded in March with the collapse of Greensill Capital, its major backer [11]). Specific verbs for The Guardian in the patterns $P A N D E M I C+$ verb as subject and verb $+P A N D E M I C$ as object are strike, affect, shine, reveal, create, take, turn, remain (e.g., Barbie recognises that all frontline workers have made tremendous sacrifices when confronting the pandemic and the challenges it heightened [11]); for the Mirror - bring, abate, inflict, scupper, kill, give, show, go on (e.g., With the coronavirus pandemic scuppering plans around the world, and while they waited for Ben to turn 18, the half-brothers had to put their plans to meet on hold [12]). 


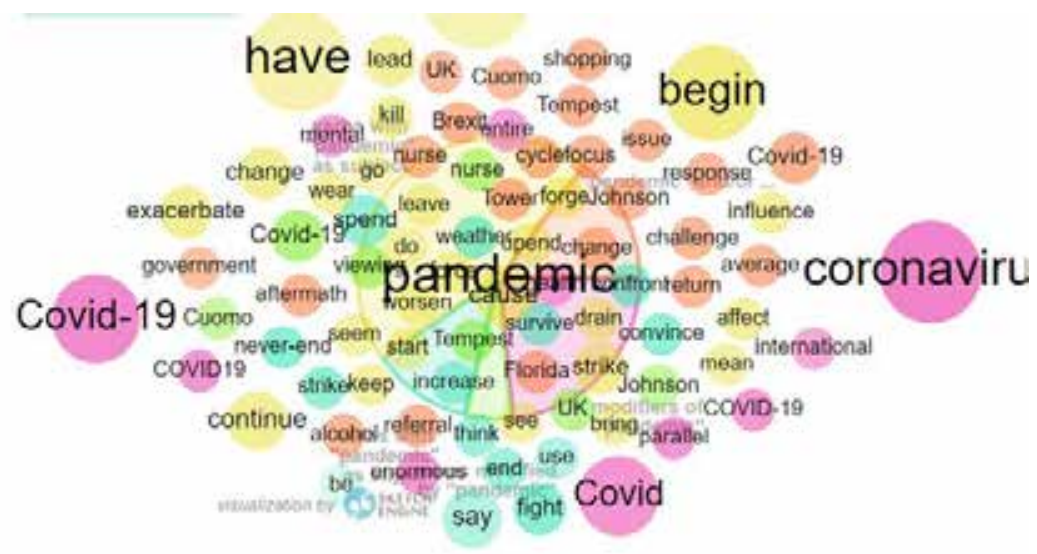

Picture 2. The n-gram of collocations with $P A N D E M I C$ in The Guardian

Collocations verbs + PANDEMIC create a metaphorical image of disaster and fight, when nations have to face a great many quite unexpected problems, and unite their forces to go through difficult times, e.g. While we desperately want to be done with this pandemic, Covid-19 is clearly not done with us, and so our battle must last a little longer [11]; The pandemic has had a devastating impact on the UK but while some places have been ravaged by Covid deaths there are 14 areas that have not had a single loss of life [12]; In May the vice-president of the Congolese national assembly said the pandemic had killed as many as 32 MPsabout 5\% of the total [11]. People and governments are portrayed as trying to find out the solution to the problem, e.g., With the pandemic continuing to cause all sorts of problems up and down the country, people are increasingly looking at ways to avoid public transport [12]; That, they said, would help fight a pandemic that has killed more than 4.25 million people worldwide [11]; We have invested £3billion so far in helping children catch up ahead of the next academic year and summer schools are an integral part of the overall effort to recover from the disruption caused by the pandemic [12]; The course of the pandemic has led to swift decisions being taken to respond to changes in our understanding of the virus and action has had to be taken in the national interest [11]. Verbal pictures present workers from healthcare field as real heroes of nowadays, e.g., During the pandemic, nurses held the hands of dying people, suppressed the fear of bringing the virus home and faced day after day of relentless, understaffed shifts [11]; She says the pandemic has exacerbated the plight of overseas nurses: "It's painful that you can give so much to a government that doesn't give anything back" [11]. Text passages containing collocations with PANDEMIC give only its starting point, while the absence of probable or supposed ending adds to the dramatic picture of calamity, e.g., Australia's second most populous state, Victoria, has gone into a seven-day lockdown - the state's sixth lockdown since the coronavirus pandemic began [11]; The news prompted dismay among the player base, particularly for American users, for whom a new wave of the pandemic is starting as the Delta variant establishes itself in the US [11]. Thus, PANDEMIC with its negative semantic prosody cannot but create gloomy, unfavourable, sometimes pessimistic depiction of what is happening right now in the world, still presenting actions both governments and people take in order to cope with the situations.

Discourse analysis of text passages with PANDEMIC has enabled to single out topics presented in the two newspapers (see Tab. 1), which are common and specific for the broadsheet. The Guardian concentrates more on fields of economy, schools, government's actions and healthcare, while The Mirror focuses on entertaining industries and community affairs. Common topics are about ordinary people's concerns, vaccination and tourism.

Topics of text passages containing collocations with PANDEMIC

Table 1.

\begin{tabular}{|l|l|}
\hline \multicolumn{1}{|c|}{ Topics } & \multicolumn{1}{c|}{ Similar for both newspapers } \\
\hline Personal stories & $\begin{array}{l}\text { I would love to say I feel sympathy towards these people, but the seemingly never-ending pandemic has drained } \\
\text { me of patience; stories like this just make me irate [11]. Before the pandemic, Rose was a happy teenager and had } \\
\text { a close group of friends. She swam for her local swimming club, played the piano and was predicted top grades } \\
\text { in school. But when lockdown struck last year, school and all her extracurricular activities came to a crashing } \\
\text { halt [12]. }\end{array}$ \\
\hline Vaccination & $\begin{array}{l}\text { We don't end this pandemic until we get the vaccination rates up." [11]. The UK's vaccination programme has } \\
\text { played a pivotal role in tackling the Covid-19 pandemic [12]. }\end{array}$ \\
\hline Travelling & $\begin{array}{l}\text { In an early sign of how brutal the pandemic was going to become, the holidaymakers had to adapt to concepts such } \\
\text { as social distancing and asymptomatic transmission [11]. But the pandemic saw a "significant drop" from applicants } \\
\text { as people were stuck at home, unable to leave their houses, let alone the country for a beach getaway [12]. }\end{array}$ \\
\hline News industry & $\begin{array}{l}\text { The Guardian } \\
\text { lifestyle reason that a number of countries around the world have developed Covid medical misinformation and } \\
\text { international pandemic [11]. }\end{array}$ \\
\hline & $\begin{array}{l}\text { TV and online video have proved an important antidote to lockdown life, with people spending a third of their } \\
\text { waking hours last year glued to screens for news and entertainment. "The pandemic undoubtedly turbocharged } \\
\text { viewing to streaming services, with three in five UK homes now signed up [11]. }\end{array}$ \\
\hline
\end{tabular}




\begin{tabular}{|c|c|}
\hline Schools & $\begin{array}{l}\text { Throughout the pandemic, our focus has been on keeping children in face-to-face education, and back in the } \\
\text { classroom as soon as possible when the nature of the pandemic meant schools could only remain open for } \\
\text { children of critical workers and vulnerable children [11]. }\end{array}$ \\
\hline Healthcare & $\begin{array}{l}\text { Overall 29\% of people receiving cancer care had a test, procedure or appointment delayed, cancelled or changed } \\
\text { during the pandemic, Cancer Research UK found [11]. }\end{array}$ \\
\hline Government & $\begin{array}{l}\text { Throughout the pandemic, Boris Johnson and his ministers have repeatedly been guilty of chaotic messaging, } \\
\text { fostering uncertainty where clarity was needed [11]. }\end{array}$ \\
\hline \multirow[t]{2}{*}{ Economy } & $\begin{array}{l}\text { Moreover, the economy will be vulnerable to negative supply shocks from de-globalisation, US-China decoupling, } \\
\text { societal ageing, migration restrictions, the curbing of the corporate sector, cyber-attacks, climate change and the } \\
\text { Covid-19 pandemic [11]. }\end{array}$ \\
\hline & The Mirror \\
\hline Mental health & $\begin{array}{l}\text { The research found living through a pandemic has exacerbated the pressure to look a certain way, with more } \\
\text { than half of adults (55 per cent) feeling lockdown has had a negative impact on their self-esteem [12]. }\end{array}$ \\
\hline Music industry & $\begin{array}{l}\text { The trio revealed that they finally decided to get back into the studio after they had their live shows cancelled } \\
\text { last year due to the Covid-19 pandemic [12]. }\end{array}$ \\
\hline Film industry & $\begin{array}{l}\text { The release itself was then delayed by the Covid-19 pandemic, with dates moving to late 2020, then early 2021, } \\
\text { and finally to } 30 \text { September, } 2021 \text { [12]. }\end{array}$ \\
\hline Minorities & London's Pride parade has been cancelled for the second year in a row due to the coronavirus pandemic [12]. \\
\hline Community affairs & $\begin{array}{l}\text { On January } 1, \text { the UK left the EU, and while our minds have been dominated by the pandemic, there have been } \\
\text { major shifts in driving rules and regulations affecting motorists travelling abroad [12]. }\end{array}$ \\
\hline
\end{tabular}

PANDEMIC is presented as a monster terrorising people, but still some text fragments demonstrate positive changes for industries, products or environment due to pandemic limits and changes in people's lifestyles. The following examples show how Motorcycle Industry Association, Sony Corporation, Wolverine Worldwide benefited from the current situation: It seems difficult to keep up with the number of new electric two-wheelers coming on to the market these days. The trend was already under way and has only been accelerated by the pandemic, with commuters and others looking for alternatives to public transport. Figures from the Motorcycle Industry Association show sales of electrics for June up 155\% compared to the same month last year [12]; Profits at Sony Corporation have climbed by more than a quarter as demand for the PlayStation 5 games console, which boomed during the Covid-19 pandemic, continues to outpace supplies [11]; Wolverine said Sweaty Betty had previously started to set up shop in the US but had used the pandemic to get out of onerous leases for bricks-and-mortar premises there, standing it in good stead to start again and grab market share more cheaply [11], which allows their businesses to boost more during tight times for others. Another example includes delivering companies: Home deliveries have soared in recent years, spurred by online shopping and the coronavirus pandemic [11], which have become of great need during pandemic limitations. Probably, the most promising achievement is connected with ecological issues: Air pollution, which is still at illegal levels in many urban areas, was also significantly reduced [11], though there are not many yet and it is difficult to say if there are any to be seen in future when the world comes to its usual routine. Nevertheless, positive sides seen in pandemic, even the smallest ones, give hope for better disregarding all difficulties.

Further research is going to be based on corpora of American broadsheets and tabloids presenting a contrastive study of results and also a comparative analysis with the results obtained in this research. We hope to see new collocations with PANDEMIC in media discourse showing its ending.

\section{References:}

1. Bublitz W. Semantic prosody and cohesive company. Leuvense Bijdragen : 85.1-2, 1996. P. 9.

2. Hoey M. Lexical Printing: A New Theory of Words and Language. London. New York, 2005. 202 p.

3. Louw B. Contextual prosodic theory: Bringing semantic prosodies to life. Birmingham : University of Birmingham, 2000. P. 158.

4. McEnery T., and Hardie A. Corpus linguistics: Method, theory and practice. Cambridge University Press, 2011. 294 p.

5. McEnery T. and Wilson A. Corpus Linguistics. Edinburgh: Edinburgh University Press, 1996. 335 p.

6. PANDEMIC. Retrieved June 10, 2021, from https://www.macmillandictionary.com/dictionary/british/pandemic

7. Sinclair J. The search for units of meaning. Textus 9, 1996. P. 87.

8. Sketch Engine. Available at: https://www.sketchengine.eu/

9. Steward D. Semantic prosody: A critical evaluation. New York. Routledge : Taylor and Francis, 2010. P. 160.

10. Teubert W. My version of corpus linguistics. International Journal of Corpus Linguistics $10: 1,2005$. P. 11.

11. The Guardian. Retrieved April-June, 2021, from https://www.theguardian.com/society/healt

12. The Mirror. Retrieved April-June, 2021, from https://www.mirror.co.uk/lifestyle/health/

13. Tognini-Bonelli E. Corpus Linguistics at Work. Amsterdam : John Benjamins Publishing Company, 2001. 236 p.

14. Turow J. Media Today. Mass Communication in a Converging World. N.Y. : Routledge, 2020. 497 p. 